RESEARCH ARTICLE

\title{
Effect of Soil Moisture Stress at Panicle Initiation and Flowering Stages on Early Morning Leaf Temperature in Rice
}

Sachin, $\mathbf{S}^{1^{*}}$, Thavaprakaash, $\mathbf{N}^{2}$, Djanaguiraman, $\mathbf{M}^{3}$ and Maragatham, $\mathbf{N}^{1}$

${ }^{1}$ Agro Climate Research Centre, Tamil Nadu Agricultural University, Coimbatore - 641003

${ }^{2}$ Department of Agronomy, Tamil Nadu Agricultural University, Coimbatore - 641003

${ }^{3}$ Department of Crop Physiology, Tamil Nadu Agricultural University, Coimbatore - 641003

Received : $20^{\text {th }}$ August, 2020

Revised : $31^{\text {st }}$ August, 2020

Accepted : $11^{\text {th }}$ September, 2020

\begin{abstract}
Field investigation on the influence of soil moisture stress (MS) on leaf temperature of rice at 0600 hours was made in Tamil Nadu Agricultural University, Coimbatore during Kuruvai (July-November) 2019 and Navarai (December-March) 2019-20 seasons. The treatments are $T_{1}$ : MS for 10 days from $\mathrm{PI}, \mathrm{T}_{2}$ : MS for 15 days from $\mathrm{PI}, \mathrm{T}_{3}$ : MS for 20 days from $\mathrm{PI}, \mathrm{T}_{4}$ : MS for 25 days from $\mathrm{PI}, \mathrm{T}_{5}$ : MS for 10 days from flowering, $\mathrm{T}_{6}$ : MS for 15 days from flowering, $T_{7}$ : MS for 20 days from flowering, $T_{8}$ : MS for 25 days from flowering and $\mathrm{T}_{9}$ : Control (Maintaining $2 \mathrm{~cm}$ of water throughout the crop period). The experiment was laid-out in Randomized Completely Block Design with three replications. Leaf temperature was measured using an infrared thermometer at 0600 hours. Moisture stress had a significant influence on the leaf temperature of rice in the early morning hours. In Kuruvai season, an increase in leaf temperature was to the tune of $0.13^{\circ} \mathrm{C}$ to $2.20^{\circ} \mathrm{C}$ during Panicle Initiation (PI) stage $\left(\mathrm{T}_{1}, \mathrm{~T}_{2}, \mathrm{~T}_{3}\right.$ and $\left.\mathrm{T}_{4}\right)$ and $0.16^{\circ} \mathrm{C}$ to $2.27^{\circ} \mathrm{C}$ during flowering stage $\left(T_{5}, T_{6}, T_{7}\right.$ and $\left.T_{8}\right)$ over control due to MS. Similarly, increased leaf temperature to the tune of $\left(0.13^{\circ} \mathrm{C}\right.$ to $2.97^{\circ} \mathrm{C}$ and $0.07^{\circ} \mathrm{C}$ to $2.96^{\circ} \mathrm{C}$ during PI stage and flowering stage, respectively) was observed due to MS treatments than MS relieved treatments and control during Navarai season. The results confirmed that the direct influence on leaf temperature of rice was due to MS irrespective of the stages and seasons. The correlation between grain yield and leaf temperature due to the MS was found to be negative.
\end{abstract}

Keywords: Rice, moisture stress, panicle initiation stage, flowering stage, leaf temperature.

\section{INTRODUCTION}

Rice is the largest and the most intensively grown food crop, supplying more than 60 per cent of the world's population with nutritious food. Rice plays a significant role in India's food security and is a means of subsistence for millions of rural families. Rice consumes about $1200 \mathrm{~mm}$ of water to complete its life cycle under irrigated condition. Hence, water is a crucial commodity and lack of availability or scarcity adversely affects the growth, development and overall accumulation of drymatter and disrupts the photosynthetic activity; resulting in reduced yield and quality (Kato et al., 2007). Moisture stress hinders the physiological activities of the plant and transpiration rate resulting in a reduction of total drymatter production.

Leaf temperature could be used as an important physiological indicator for determining the opening or closure of stomata due to the response of crop under soil water stress (Jones et al., 2009). Halder and Burrage (2003) indicated that increasing water (moisture) stress reduced the transpiration rate with an increase of leaf temperature in rice. Yan et al. (2012) reported that temperature of panicle and leaves were much higher under extreme water stress; reduced photosynthetic rate, transpiration rate and stomatal conductance.

Though there are confirmed studies on leaf temperature due to moisture stress, there are limited reports on the influence of moisture stress period in two most critical stages of rice for irrigation (panicle initiation and flowering) on leaf temperature in tropical condition. Hence, the present study was made in two different seasons, viz., rainy (Kuruvai) and non-rainy (Navarai) to assess the impact of leaf temperature of rice in early morning hours due to the moisture stress.

\section{MATERIAL AND METHODS}

The field investigation was carried out in Wetland farm of the Department of Agronomy, Tamil Nadu Agricultural University, Coimbatore during Kuruvai 
(July-November) 2019 and Navarai (DecemberMarch) 2019-20 seasons under irrigated condition. The experimental site is located in a semi-arid tropical region $\left(11.0^{\circ} \mathrm{N}\right.$ latitude, $77.0^{\circ} \mathrm{E}$ longitude and $426.7 \mathrm{~m}$ above mean sea level). The average annual rainfall of the region is $746.5 \mathrm{~mm}$, which received in 47 rainy days. Soil of experimental field was clay loam in texture with medium organic carbon $(0.70$ and $0.67 \mathrm{~g} \mathrm{~kg}^{-1}$ ), low available nitrogen (213.2 and 238.4 Kg ha-1), high available phosphorus (47.2 and $42.0 \mathrm{Kg} \mathrm{ha}^{-1}$ ) and high available potassium (642.8 and $1046.8 \mathrm{Kg} \mathrm{ha}^{-1}$ ) during Kuruvai and Navarai seasons, respectively.

The experiment was laid-out in a Randomized Completely Block Design (RCBD) with three replications and nine treatments were allotted at random. The treatments are as follows, $T_{1}$ - Moisture stress for 10 days from PI, $\mathrm{T}_{2}$ - Moisture stress for 15 days from $\mathrm{PI}, \mathrm{T}_{3}$ - Moisture stress for 20 days from $\mathrm{PI}$, $\mathrm{T}_{4}$ - Moisture stress for 25 days from $\mathrm{PI}, \mathrm{T}_{5}$ - Moisture stress for 10 days from flowering, $T_{6}$ - Moisture stress for 15 days from flowering, $T_{7}$ - Moisture stress for 20 days from flowering, $T_{8}$ - Moisture stress for 25 days from flowering and $T_{9}$ - Control (Maintaining $2 \mathrm{~cm}$ of water throughout the crop period). Moisture stress was imposed in the field by withdrawing water from the concerned plots; and not irrigating up to the specified moisture stress period. The seepage was arrested through buffer channels and bunds surrounding the plot. In addition to that, a polythene sheet at a depth of $30 \mathrm{~cm}$ was also inserted in all four sides of the bunds of plots to arrest the lateral movement of water between plots. All other packages of practices was followed to raise the crop as specified in CPG (2012).

Leaf temperature $\left({ }^{\circ} \mathrm{C}\right)$ was measured using an infrared thermometer (Foopro, Raytek, USA). The observations were recorded at early morning (0600 hrs.) at 3 days interval after the moisture stress $\left(1^{\text {st }}, 4^{\text {th }}, 7^{\text {th }}, 10^{\text {th }}, 13^{\text {th }}, 16^{\text {th }}, 19^{\text {th }}, 22^{\text {nd }}\right.$ and $25^{\text {th }}$ day after moisture stress) in both panicle initiation and flowering stages. Data subjected to statistical analysis as given by Gomez and Gomez (2010) for RCBD. The correlation was made to know the relationship between grain yield and leaf temperature.

\section{RESULTS AND DISCUSSION}

The experimental results showed that moisture stress had a significant effect on the early morning leaf temperature of rice in both Kuruvai and Navarai seasons (Table 1 and 2), barring at one Day After Moisture Stress (DAMS) in both panicle initiation and flowering stages.

Table 1. Effect of moisture stress on leaf temperature $\left({ }^{\circ} \mathrm{C}\right)$ during 0600 hours in Kuruvai 2019 season

\begin{tabular}{|c|c|c|c|c|c|c|c|c|c|c|c|c|c|c|c|c|c|c|}
\hline \multirow{3}{*}{ Treatments } & \multicolumn{18}{|c|}{ Days after stress } \\
\hline & \multicolumn{16}{|c|}{ Panicle initiation stage } & \multicolumn{2}{|c|}{ Flowering stage } \\
\hline & 1 & 4 & 7 & 10 & 13 & 16 & 19 & 22 & 25 & 1 & 4 & 7 & 10 & 13 & 16 & 19 & 22 & 25 \\
\hline$T_{1}$ & 24.30 & 24.53 & 26.20 & 26.70 & 24.60 & 24.33 & 24.53 & 25.67 & 25.33 & 24.20 & 25.30 & 26.40 & 25.43 & 25.67 & 24.47 & 25.40 & 25.43 & 25.47 \\
\hline $\mathrm{T}_{2}$ & 24.20 & 24.47 & 26.30 & 26.53 & 25.72 & 24.63 & 24.50 & 25.57 & 25.53 & 24.40 & 25.57 & 26.43 & 25.63 & 25.50 & 24.60 & 25.37 & 25.47 & 25.57 \\
\hline $\mathrm{T}_{3}$ & 24.33 & 24.53 & 26.40 & 26.70 & 25.50 & 25.53 & 25.60 & 25.33 & 25.17 & 24.67 & 25.47 & 26.83 & 25.63 & 25.77 & 24.47 & 25.47 & 25.20 & 25.27 \\
\hline $\mathrm{T}_{4}$ & 24.40 & 24.60 & 26.47 & 26.70 & 25.70 & 25.40 & 25.47 & 27.73 & 27.60 & 24.20 & 25.33 & 26.50 & 25.47 & 25.67 & 24.33 & 25.57 & 25.47 & 25.63 \\
\hline$T_{5}$ & 24.33 & 23.40 & 25.47 & 25.30 & 24.17 & 24.27 & 24.67 & 25.60 & 25.30 & 24.53 & 26.53 & 27.60 & 26.40 & 25.67 & 24.60 & 25.27 & 25.57 & 25.33 \\
\hline $\mathrm{T}_{6}$ & 24.50 & 23.70 & 25.50 & 25.20 & 24.47 & 24.63 & 24.37 & 25.47 & 25.43 & 24.57 & 26.33 & 27.53 & 26.43 & 26.57 & 24.47 & 25.57 & 25.47 & 25.57 \\
\hline $\mathrm{T}_{7}$ & 24.60 & 23.70 & 25.43 & 25.57 & 24.60 & 24.53 & 24.43 & 25.40 & 25.57 & 24.63 & 26.53 & 27.60 & 26.57 & 26.67 & 25.60 & 26.47 & 25.20 & 25.53 \\
\hline $\mathrm{T}_{8}$ & 24.47 & 23.20 & 25.50 & 25.47 & 24.30 & 24.67 & 24.40 & 25.47 & 25.57 & 24.57 & 26.70 & 27.63 & 26.67 & 26.67 & 25.20 & 26.27 & 27.47 & 27.47 \\
\hline $\mathrm{T}_{9}$ & 24.27 & 23.20 & 25.40 & 25.20 & 24.47 & 24.50 & 24.57 & 25.57 & 25.40 & 24.47 & 25.77 & 26.80 & 25.53 & 25.47 & 24.60 & 25.27 & 25.20 & 25.47 \\
\hline SEd & 0.23 & 0.16 & 0.24 & 0.21 & 0.21 & 0.29 & 0.25 & 0.24 & 0.24 & 0.22 & 0.25 & 0.19 & 028 & 0.18 & 0.23 & 0.16 & 0.27 & 0.27 \\
\hline $\mathrm{CD}(5 \%)$ & NS & 0.34 & 0.51 & 0.45 & 0.44 & 0.61 & 0.53 & 0.51 & 0.52 & NS & 0.51 & 0.39 & 0.60 & 0.38 & 0.49 & 0.33 & 0.58 & 0.57 \\
\hline \multicolumn{19}{|c|}{ NS - Non significant } \\
\hline \multicolumn{12}{|c|}{$T_{1}-$ Moisture stress for 10 days from panicle initiation stage } & \multicolumn{7}{|c|}{$T_{5}-$ Moisture stress for 10 days from flowering stage } \\
\hline \multicolumn{12}{|c|}{$T_{2}-$ Moisture stress for 15 days from panicle initiation stage } & \multicolumn{7}{|c|}{$T_{6}-$ Moisture stress for 15 days from flowering stage } \\
\hline \multicolumn{12}{|c|}{$\mathrm{T}_{3}-$ Moisture stress for 20 days from panicle initiation stage } & \multicolumn{7}{|c|}{$\mathrm{T}_{7}-$ Moisture stress for 20 days from flowering stage } \\
\hline \multicolumn{11}{|c|}{$\mathrm{T}_{4}-$ Moisture stress for 25 days from panicle initiation stage } & & \multicolumn{7}{|c|}{$\mathrm{T}_{8}-$ Moisture stress for 25 days from flowering stage } \\
\hline
\end{tabular}

During Kuruvai season, on 4 DAMS at PI stage, significantly higher leaf temperature $\left(24.60^{\circ} \mathrm{C}\right)$ was recorded in the treatment $\mathrm{T}_{4}$ compared to all other non-stress-imposed treatments $\left(\mathrm{T}_{5}, \mathrm{~T}_{6}, \mathrm{~T}_{7}\right.$ and $\left.\mathrm{T}_{8}\right)$ and control $\left(\mathrm{T}_{9}\right)$. However, higher values recorded in the treatment $T_{4}$ was on par with other moisture stress imposed treatments, such as $T_{1}, T_{2}$ and $T_{3}$. Similar results were obtained on 7 and 10 DAMS. On 13 DAMS, $T_{1}$ treatment and on 16 and 19 DAMS, $T_{1}$ and $T_{2}$ treatments, which were relieved from moisture stress, recorded significantly lower but on par leaf temperature values with the non-stressed treatments $\left(T_{5}, T_{6}, T_{7}\right.$ and $\left.T_{8}\right)$ and control. On 22 and 25 DAMS, the treatment $\mathrm{T}_{4}$ alone was imposed moisture stress and registered significantly higher leaf temperature $\left(27.73^{\circ} \mathrm{C}\right)$ than all other treatments under study. Control treatment $\left(\mathrm{T}_{9}\right)$, which was supplied with continuous moisture without any stress, recorded the lowest leaf temperature throughout the observation period. 
On 4 DAMS of flowering stage, when compared to stress relieved treatments $\left(T_{1}, T_{2}, T_{3}\right.$ and $\left.T_{4}\right)$ and control $\left(T_{9}\right)$, treatment $T_{8}$ recorded significantly higher leaf temperature $\left(26.70^{\circ} \mathrm{C}\right)$, but was on par with other moisture stress imposed treatments $\left(T_{5}\right.$, $\mathrm{T}_{6}$ and $\mathrm{T}_{7}$ ). Similarly, on 7 and 10 DAMS also, the moisture stress imposed treatments $\left(T_{5}, T_{6}\right.$ and $T_{7}$ and $T_{8}$ ) shown increased leaf temperature values. On 13 DAMS, $T_{6}, T_{7}$ and $T_{8}$ treatments, which were under continuous moisture stress, recorded warmer leaves $\left(26.67^{\circ} \mathrm{C}\right)$ but $\mathrm{T}_{5}$ treatment (stress relieved on $10^{\text {th }}$ DAMS) recorded lower temperature. Moisture stress continued treatments $\left(T_{7}\right.$ and $\left.T_{8}\right)$ consistently recorded more leaf temperature on 16 and 19 DAMS compared to all other stress relieved treatments during PI stage $\left(T_{1}, T_{2}, T_{3}\right.$ and $\left.T_{4}\right)$ and during flowering stage $\left(T_{5}\right.$ and $\left.T_{6}\right)$ and also in control. Similarly, on 22 and 25 DAMS, the treatment $\mathrm{T}_{8}$ recorded significantly more leaf temperature values than all other stress-relieved treatments of both PI and flowering stages and control. Similar nature of results was reproduced during the Navarai 2019-20 season, also with increased leaf temperature values.

Table 2. Effect of moisture stress on leaf temperature $\left({ }^{\circ} \mathrm{C}\right)$ during 0600 hours in Navarai $2019-20$ season

\begin{tabular}{|c|c|c|c|c|c|c|c|c|c|c|c|c|c|c|c|c|c|c|}
\hline \multirow{3}{*}{ Treatments } & \multicolumn{18}{|c|}{ Days after stress } \\
\hline & \multicolumn{16}{|c|}{ Panicle initiation stage } & \multicolumn{2}{|c|}{ Flowering stage } \\
\hline & 1 & 4 & 7 & 10 & 13 & 16 & 19 & 22 & 25 & 1 & 4 & 7 & 10 & 13 & 16 & 19 & 22 & 25 \\
\hline$T_{1}$ & 24.80 & 19.40 & 21.60 & 24.63 & 24.57 & 24.33 & 24.23 & 25.43 & 25.50 & 24.27 & 23.00 & 23.33 & 23.00 & 23.70 & 23.57 & 23.60 & 23.60 & 23.50 \\
\hline$T_{2}$ & 25.13 & 19.50 & 21.40 & 25.07 & 25.43 & 24.63 & 24.67 & 25.63 & 25.50 & 24.33 & 23.57 & 23.57 & 23.23 & 23.30 & 23.70 & 23.57 & 23.20 & 23.43 \\
\hline $\mathrm{T}_{3}$ & 24.67 & 19.23 & 21.53 & 24.90 & 25.30 & 26.67 & 27.37 & 25.63 & 25.93 & 24.83 & 23.73 & 23.53 & 23.27 & 23.63 & 23.43 & 23.77 & 23.57 & 23.47 \\
\hline $\mathrm{T}_{4}$ & 24.50 & 19.23 & 21.40 & 25.00 & 25.27 & 26.77 & 27.03 & 27.47 & 28.23 & 24.47 & 23.57 & 23.43 & 23.10 & 23.63 & 23.57 & 23.67 & 23.63 & 23.37 \\
\hline $\mathrm{T}_{5}$ & 24.97 & 18.63 & 20.43 & 23.63 & 24.63 & 24.50 & 24.47 & 25.47 & 25.60 & 24.53 & 24.63 & 25.57 & 25.50 & 24.30 & 23.57 & 23.53 & 23.67 & 23.73 \\
\hline $\mathrm{T}_{6}$ & 24.93 & 18.40 & 20.20 & 23.57 & 24.87 & 24.47 & 24.33 & 25.60 & 25.67 & 24.70 & 24.67 & 25.73 & 25.77 & 25.57 & 24.57 & 23.63 & 23.50 & 23.43 \\
\hline $\mathrm{T}_{7}$ & 24.87 & 18.60 & 20.20 & 23.40 & 24.70 & 24.63 & 24.47 & 25.73 & 25.73 & 24.63 & 24.50 & 25.50 & 25.43 & 25.60 & 25.70 & 25.40 & 24.47 & 23.63 \\
\hline$T_{8}$ & 24.70 & 18.63 & 20.70 & 23.37 & 24.67 & 24.37 & 24.67 & 25.30 & 25.20 & 24.87 & 24.50 & 25.53 & 25.70 & 25.60 & 25.67 & 25.73 & 25.73 & 26.23 \\
\hline $\mathrm{T}_{9}$ & 24.47 & 18.37 & 20.00 & 23.20 & 24.63 & 24.20 & 24.40 & 25.30 & 25.30 & 24.17 & 22.93 & 23.20 & 23.00 & 23.23 & 23.37 & 23.40 & 23.60 & 23.27 \\
\hline SEd & 0.33 & 0.35 & 0.33 & 0.62 & 0.27 & 0.22 & 0.27 & 0.27 & 0.21 & 0.52 & 0.46 & 0.50 & 0.27 & 0.25 & 0.19 & 0.53 & 0.14 & 0.18 \\
\hline $\mathrm{CD}(5 \%)$ & NS & 0.74 & 0.70 & 1.31 & 0.57 & 0.46 & 0.58 & 0.57 & 0.45 & NS & 0.97 & 1.06 & 0.58 & 0.53 & 0.41 & 1.12 & 0.30 & 0.39 \\
\hline
\end{tabular}

$T_{1}-$ Moisture stress for 10 days from panicle initiation stage

$\mathrm{T}_{2}$ - Moisture stress for 15 days from panicle initiation stage

$\mathrm{T}_{3}$ - Moisture stress for 20 days from panicle initiation stage

$\mathrm{T}_{4}-$ Moisture stress for 25 days from panicle initiation stage

The results of the field experiment over two seasons revealed that there was a significant difference between the moisture stress imposed treatments and continuously irrigated treatments during the PI stage; and moisture stress imposed treatments and moisture stress relieved treatments in flowering stage on leaf temperature of rice. At both panicle initiation and flowering stages, moisture stress had influenced the early morning leaf temperature significantly. Warmer leaves were noted in terms of leaf temperature when the moisture stress was imposed compared to the moist fields. When days of moisture stress increased (from $1^{\text {st }}$ day to $25^{\text {th }}$ days) both in $\mathrm{PI}$ and flowering stages, leaf temperature increased correspondingly. The reason for the increased leaf temperature was due to that moisture stress obliviously reduced the moisture availability in the soil system first and followed by in plant system, in turn, reduces the turgidity of plant. Also, the loss of water in plant, especially in leaves, would reduce the transpiration rate and increase the internal temperature.

Relative water content (RWC) was directly related to the MS and had a close relationship with leaf temperature of rice. In the present investigation, RWC values were decreased (Data not given)
$T_{5}-$ Moisture stress for 10 days from flowering stage

$\mathrm{T}_{6}$ - Moisture stress for 15 days from flowering stage

$\mathrm{T}_{7}$ - Moisture stress for 20 days from flowering stage

$T_{8}$ - Moisture stress for 25 days from flowering stage

$\mathrm{T}_{9}$ - Control - Maintaining $2 \mathrm{~cm}$ of water throughout the crop period

even moisture stress was given for a day and the RWC values were declined drastically when the stress duration progressed ( $1^{\text {st }}$ day to $25^{\text {th }}$ days). Similarly, Siddique et al. (2000) revealed that the temperature of leaf had been increased under water deficit conditions resulting in lower leaf water potential, relative water content and transpiration rate in wheat crop. Increment in leaf temperature also increased the canopy temperature of the rice. Similarly, Takai et al. (2010) identified the strong connection between canopy temperature with leaf temperature in photosynthetic system. Rice cultivars that experienced a substantial loss of production under water stress had the greatest decline in carbohydrate accumulation and relatively increased the chlorophyll content (SPAD) content and leaf temperature (Tm), respectively (Barnaby et al., 2019).

The observation in Kuruvai season revealed that increase in leaf temperature due to moisture stress was in the range of $0.13^{\circ} \mathrm{C}$ to $2.20^{\circ} \mathrm{C}$ during PI stage; and $0.16^{\circ} \mathrm{C}$ to $2.27^{\circ} \mathrm{C}$ during flowering stage. Warmness in terms of leaf temperature due to moisture stress during Navarai season ranged between $0.13^{\circ} \mathrm{C}$ to $2.97^{\circ} \mathrm{C}$ and $0.07^{\circ} \mathrm{C}$ to $2.96^{\circ} \mathrm{C}$, at $\mathrm{PI}$ and flowering stages, respectively. Yan et al. (2012) 
also observed that under severe moisture stress conditions, the leaf temperature was increased to the tune of $3^{\circ} \mathrm{C}$. Surendar et al. (2013) also documented the, $2^{\circ} \mathrm{C}$ to $3^{\circ} \mathrm{C}$ increase of leaf temperature due to water deficit over control. The current study results were also corroborated to the earlier studies that moisture stress increased leaf temperature values. The increase of leaf temperature due to moisture stress was more pronounced in Navarai season compared to Kuruvai season. The increased leaf temperature during Navarai season was that there was no intermittent rainfall until maturity phase, which caused severe deficit of moisture to the plants and in turn made reduced availability of water and increased range of leaf temperature. Whereas, Kuruvai season which coincides with the southwest monsoon season, there were rainfall in-between crop growth that reduced the increment range of leaf temperature.

Yield is the ultimate goal of any crop cultivation. There existed a reduction of grain yield and straw yield of rice due to MS. The correlation analysis between leaf temperature and grain yield of rice indicated that there was a negative correlation (-0.72 to -0.16). Zheng et al. (2006) and Wang et al. (2004) also inferred earlier that the moisture stress influenced strongly on reduction of grain yield of rice.

\section{CONCLUSION}

The present study concluded that water stress had a significant influence on leaf temperature in the early morning hours. An increase of moisture stress period irrespective of season and stage of rice, enhanced the leaf temperature. The range of increased leaf temperature due to the prolonged MS (25 days) was $2.20^{\circ} \mathrm{C}$ and $2.27^{\circ} \mathrm{C}$ at PI and flowering stages, respectively in Kuruvai season. In Navarai season, increased leaf temperature due to extending moisture stress (25 days) was $2.97^{\circ} \mathrm{C}$ and $2.96^{\circ} \mathrm{C}$ at $\mathrm{PI}$ and flowering stages, respectively. A negative correlation between rice yield and leaf temperature at 0600 hours was also observed.

\section{REFERENCES}

Barnaby, J. Y., Rohila, J. S., Henry, C. G., Sicher, R. C., Reddy, V. R. and A. M. McClung. 2019. Physiological and metabolic responses of rice to reduced soil moisture: Relationship of water stress tolerance and grain production. Int. J. Mol. Sci., 20(8): 1846.
CPG. 2012. Crop Production Guide. Government of Tamil Nadu and Tamil Nadu Agricultural University, Coimbatore, Tamil Nadu.

Gomez, K. and A. A. Gomez. 2010. Statistical procedures for agricultural research. $2^{\text {nd }}$ edition. An international rice research institute book. $A$ Wiley-Interscience Publication, New York.

Halder, K. P. and S. W. Burrage. 2003. Drought stress effects on water relations of rice grown in nutrient film technique. Pakistan J. Biol. Sci., 6(5): 441444.

Jones, H. G., Serraj, R., Loveys, B. R., Xiong, L., Wheaton A. and A. H. Price. 2009. Thermal infrared imaging of crop canopies for the remote diagnosis and quantification of plant responses to water stress in the field. Funct. Plant Biol., 36: 978-989.

Kato, Y., Kamoshita, A., Yamagishi, J., Imoto, H. and J. Abe. 2007. Growth of rice (Oryza sativa L.) cultivars under upland conditions with different levels of water supply. Plant Prod. Sci., 10(1): 3-13.

Siddique, M., Hamid, A. and M. Islam. 2000. Drought stress effects on water relations of wheat. Bot. Bull. Acad. Sinica, 41: 35-39.

Surendar, K. K., Devi, D. D., Ravi, I., Jeyakumar, P. and K. Velayudham. 2013. Effect of water stress on leaf temperature, transpiration rate, stomatal diffusive resistance and yield of banana. Plant Gene Trait, 4(8): 43-47.

Takai, T., Yano, M. and T. Yamamoto. 2010. Canopy temperature on clear and cloudy days can be used to estimate varietal differences in stomatal conductance in rice. Field Crops Res., 115: 165170.

Wang, W., Zhang, J. H., Yang, J. C. and Q. S. Zhu. 2004. Effect of water stress on metabolism of stored carbohydrate of stems and yields in rice grown under unfavorable-delayed senescence. Acta Agronomica Sinica, 30(3): 196-204.

Yan, C., Chen, H., Fan, T., Huang, Y., Yu, S., Chen S. and X. Hong. 2012. Rice flag leaf physiology, organ and canopy temperature in response to water stress. Plant Prod. Sci., 15(2): 92-99.

Zheng, B. S., Ling, Y. A. N. G., Chuan-Zao, M. A. O., Zhang, W. P. and W. U. Ping. 2006. QTLs and candidate genes for rice root growth under flooding and upland conditions. Acta Genetica Sinica, 33(2): 141-151. 